\title{
Proximate Composition, Minerals and Sensory Acceptability of Deep Fried Nile Tilapia Fish (Oreochromis niloticus) as Influenced by Repeated Use of Palm Oil
}

\author{
Aemiro Tadesse \\ School of Nutrition, Food Science and Technology, Hawassa University, Ethiopia \\ Abadi Gebre \\ School of Nutrition, Food Science and Technology, Hawassa University, Ethiopia \\ Gezahegn Nigusse \\ Schools of Nutrition, Food Science and Technology, Hawassa University, Ethiopia \\ Derese Tamiru \\ Schools of Nutrition, Food Science and Technology, Hawassa University, Ethiopia
}

\begin{abstract}
The research is financed by Hawassa University (Thematic grant)
Abstract

Background: Fish fryer adapted reusing of frying oil to minimize cost and health problems are reported on reusing of frying oil. This study was aimed to determine Chemical and sensory properties of deep fried Nile tilapia fish (oreochromis niloticus) as influenced by repeated use of palm oil.Method: Preliminary survey was conducted as baseline for the experiment. Data were collected for cooperative unions who work in fish market or informally known as (Gudumale Park, Fikir hayik and Tikur wuha). The experiment was designed and conducted using data collected from unions and proximate composition, Minerals ( $\mathrm{Ca}, \mathrm{P}, \mathrm{Fe}$ and $\mathrm{Zn}$ ) and sensory acceptability were analyzed. SPSS for windows version 20 and SAS for windows version 9 were used for analysis.Result: Preliminary survey showed fried fish consumption and repeatedly using of palm oil for frying is accustomed practice around the lake. Proximate composition indicates as frying cycle increases ash and crude fat were increased while protein and moisture were decreased. However, total carbohydrate was not significantly different. As frying cycle increases $\mathrm{Ca}, \mathrm{P}, \mathrm{Fe}$ and $\mathrm{Zn}$ were decreased. In case of sensory properties color and appearance of fried fish from cycle 1 to cycle 3 had better preference. However, the rest cycle had lower color and appearance acceptability. Similarly, odor of fried fish from cycle 1 to cycle 4 had better preference as compared to cycle 5 and cycle 6.Conclusion: Thus it can be concluded that repeatedly using of palm oil has effect on proximate composition, Minerals ( $\mathrm{Ca}, \mathrm{P}, \mathrm{Fe}$ and $\mathrm{Zn}$ ) and sensory acceptability deep frying of Nile tilapia fish due to deteriorated frying palm oil has drawn in to frying fish as the moisture is evaporated and this could be harmful to human health. Therefore frequent replacing of oil could be better.
\end{abstract}

Keywords: Chemical, Sensory properties, Palm oil, Lake side Hawassa

DOI: $10.7176 / \mathrm{FSQM} / 95-03$

Publication date:March $31^{\text {st }} 2020$

\section{Introduction}

Fish has essential nutrient for healthy body building (Chukwu and Mohammed, 2009). The total exploitable fish potential in Ethiopia is about 51, 500 tons per annum (Kebede et al., 2017). There are many lakes found in Ethiopia as potential source of fish and of this Lake Tana, Koka, Ziway, Langano, Hawassa, Abaya and Chamo are commonly known (Vijverberg et al., 2012). Lake Hawassa is one of the Rift Valley Lake of Ethiopia and it is used greatly for tourism attraction and supplies fish for local communities (Alemu et al., 2017). The lake has important role in the lives of many people and the lake being used as a source of commercial value and three locally processed fish are available around the lake fried fish, fish fillet and fish soup.

From those locally processed fish fried fish is the most liked and consumed products by the people and it has high commercial value as compared to other processed fish. Currently fried food consumption is become popular and good economical source worldwide (Al-Saghir et al., 2004). Two commonly type of frying is applied which is shallow and deep frying and this could change the chemical and nutritional composition of frying food (Echarte et al., 2001; Moradi et al., 2011). Repeatedly using of oil during frying is become commonly adapted and this practice commonly adapted around the Lake side Hawassa in the fried fish buisness. Due to fish can easily be affected during processing and when the oil used many times the chemical and sensory properties of fried fish will be affected. Benedito et al., 2007) stated that reusing the oil during frying for long time brought a change in physicochemical properties of the oil (increased in oil viscosity, oxidation) and oil uptake in fried potato.

The uptake of oil by the fried potato is due to the formation of porous structure when moisture evaporated 
and result the oil to be drawn to the food (Rossi et al., 2009). Thus it is important to study the chemical and sensory properties instability of fried fish as the oil is used repeatedly. Therefore, the aim of this study was to study the proximate composition, Mineral content and sensory acceptability of deep fried Nile tilapia fish as the palm oil is repeatedly used based on survey as baseline for the experiment.

\section{Methods \\ Preliminary survey}

Sampling site was visited before conducting the experiment to facilitate the experimental work. open ended type of questions with face to face interview based data collection was conducted to assess fish processing, frying and fried fish consumption practices at Hawassa lake side. The data was collected from the cooperative fisher men who works in fish frying landing site called fish market or informally known as (Gudumale Park, Fiker hayik and Tikur wuha). All the unions were used in the survey. Specifically, the collected information includes; educational background, experience in the fish frying business, their knowledge and attitudes toward reusing frying oil and also fish frying related data: like (i) type of fish they mostly caught and fry (ii) the trend of frying (iii) kind of frying (iv) type of oil they are using for frying (v) frequency of oil reusing and (vi) fried fish market. Additionally time taken and temperature were measured from all union involved in fish frying market.

\section{Sample collection and preparation}

Sampling operation was carried out during dry season. Tilapia fish species $(n=24)$ weighing around $150 \mathrm{~g}$ was collected from (Gudumale Park) fish purchasing and distributing site. The fish was immediately dissected in the field and it was cleaned, descaled and eviscerated manually using sterile plastic knife (Njinkoue et al., 2016). The edible part (flesh and skin) was transferred in plastic bags and was kept in ice box at temperature $4^{\circ} \mathrm{C}$ with a fish/ice ratio of $1: 2$ and then transported to the laboratory.

\section{Frying method}

The preliminary survey indicated that mostly practiced frying temperature and time was $170^{\circ} \mathrm{C}$ and 10 min. Thus, fish samples (weighing $110 \mathrm{~g}$ ) in this study were deep fried in palm oil at $170^{\circ} \mathrm{C}$ for $10 \mathrm{~min}$ for each frying cycles (frying cycle 1-6). All fried fishes were drained for 15 seconds to remove excess oil. The samples were prepared according to (Weber et al., 2008). After removing the central vertebra back bone, the fried fishes were oven dried at $60^{\circ} \mathrm{C}$ for $72 \mathrm{hr}$ then transferred into desiccators and cooled for $30 \mathrm{~min}$. dried fishes were grounded to $0.3 \mathrm{~mm}$ size mill and the powder was stored in desiccators for analysis. Samples were homogenized by passing them twice through a mincer with $4 \mathrm{~mm}$ holes and mixed thoroughly. Uniformity of the homogenate was ensured by further mixing. The resultant homogenate was packed into several small convenient sterile containers and stored at $0^{\circ} \mathrm{C}$ until analysis. The experiment was conducted in duplicate for proximate composition and sensory properties.

\section{Determination of Proximate composition}

The proximate composition of deep fried fish with recycled oil was determined according to (AOAC, 1998). The moisture content was determined using official method 934.01; ash content was determined using official method 923.03, crude fat content was determined using official method of 920.39; crude protein was determined using official method of 981.10 and total carbohydrate was determined by difference method.

\section{Determination of Mineral}

Iron and Zinc were determined by Flame atomic absorption spectrophotometers (AAS) according to modified AOAC (1998) using official method of 985.35. Ca was determined by EDTA Titrimetric Method according to modified AOAC (1998) using official method of 985.35. Modified AOAC 923.03 method was used for ashing. Total phosphorus (TP) was determined by Photometric Method according to AOAC (2000) using official method of 965.17.

\section{Sensory acceptability evaluation of fried fish}

Totally 20 Panelists were randomly selected and requested to evaluate the fried fish. The sensory attributes are color, flavor, odor, appearance and over all acceptability. The fried fishes were placed in a pan coded with random numbers and kept for a minimum of 30 min for ensuring uniform temperature (room temperature) in all fried fish, then water for rinsing and fried fishes were presented to the panelists for analyzing sensorial property. Each cycle were assessed in triplicate by the panelist with five-point hedonic scales. The panelists were asked to evaluate their preference and to score from $1=$ dislike very much, $2=$ dislike, $3=$ neither like nor dislike, $4=$ like and $5=$ like very much.

\section{Data analyses}

Frying of fish was performed twice for all samples and closely agreeing replicates were obtained. The proximate composition and sensory acceptability analyses on both replicates were repeated at least twice. The data for preliminary survey were analyzed using SPSS statistic 21 and the data for proximate composition, minerals and sensory property were analyzed using SAS version 9 with one-way ANOVA. The means were separated using Tukey's HSD test at $\mathrm{p}<0.05$. 


\section{Result and Discussion}

Assessment of consumption, frying and marketing of fish at Hawassa Lake Side

The study considered totally 18 unions from three site of Lake Hawassa (Gudumale Park, Tikur wuha and Fikir Hayik) who are involved in fish frying business. The preliminary assessments result showed $72.2 \%$ of the fryers were from primary education level (Table 1). It also indicated that $83.3 \%$ of fish fryer in the union had working experience of 1 year and above. The study indicated $66.7 \%$ of the union purchases ( $\geq 60$ fishes) per day and $33.3 \%$ of the union purchased 40 fishes per day. The result showed $83.4 \%$ of the unions fry fish after 5 min of purchasing and/or fishing so as to heat the oil before frying. Around $83.3 \%$ of the unions had ice room for storage of raw fishes. Fried fish was the most commonly processed fish at Hawassa Lake Side and all unions serve the fried fish to customer. About $88.9 \%$ of the unions were not well informed about food safety related to fish. Only $12 \%$ of fish fryer in the union access food safety information from media, health worker, family, and friends.

The most commonly catched, purchased, fried and consumed fish at Hawassa Lake Side was Nile tilapia (Koroso) and this species was used by all unions. The maximum frying time and amount of oil used by most unions (77.8\% respondents) were $10 \mathrm{~min}$ and 5 liters respectively. The result showed, all the union (100\%) uses palm oil for fish frying. The maximum frying cycle used by most unions (66.7\% respondent) were six cycles and from total union about $83.3 \%$ of the union purge last used oil after six cycles, while the rest $16.7 \%$ of the union uses the oil for firing purpose. After frying all union put fried fishes in open air by hanging on a wood to collect the oil leaks from fried fishes and the maximum duration of storing fried fishes before serving to customer in most union $(66.7 \%$ respondents) were $30 \mathrm{~min}$.

\section{Proximate composition of raw and deep fried fish with recycled palm oil}

Proximate compositions of raw and fried fish were presented (Table 4.2). Moisture content of fried fishes varied considerably from 7.84 to $6.92 \%$. Fried fishes from different cycles $(\mathrm{C} 1, \mathrm{C} 2, \mathrm{C} 3, \mathrm{C} 4, \mathrm{C} 5$ and $\mathrm{C} 6)$ had lower $(\mathrm{p}<0.05)$ moisture level compared to un-fried fish (CR). However, fried fishes from C4, C5 and C6 had similar (p $\geq 0.05)$ moisture level compared to reference (CL-commercial fried fish). Fried fishes from $\mathrm{C} 1, \mathrm{C} 2$, and $\mathrm{C} 3 \mathrm{had}$ higher ( $\mathrm{p}$ $<0.05$ ) moisture level compared to commercial fried fish. Regarding to the effect of frying cycles, C3, C4, C5 and C6 had lower $(\mathrm{p}<0.05)$ moisture compared C1 and C2 (lower cycles). This showed that increasing the frying cycle decreased moisture level of fried fish. The lower in moisture of fried fishes might be due to increased frying cycle causing moisture of fish to evaporate and move out from core of fish to crust and frying oil could be drawn in to frying fish (Mellema, 2003). The study is consistent with Gokoglu et al., (2004) who reported low level of moisture in rainbow trout fish fried at different frying temperature.

Ash content of fried fish varied from 6.87 to 7.94\%. Fried fishes from different cycles $(\mathrm{C} 2, \mathrm{C} 3, \mathrm{C} 4, \mathrm{C} 5$ and C6) had higher $(\mathrm{p}<0.05)$ ash content compared to un-fried fish $(\mathrm{CR})$, but $\mathrm{C} 1$ had similar $(\mathrm{p} \geq 0.05)$ ash content compared to un-fried fish (CR). However, fried fishes from C3, C4, C5 and C6 had similar ( $\mathrm{p} \geq 0.05)$ ash content compared to reference (CL-commercial fried fish). Fried fishes from $\mathrm{C} 1$ and $\mathrm{C} 2$ had lower $(\mathrm{p}<0.05)$ ash content compared to (CL-commercial fried fish). Concerning effect of frying cycles, C3, C4, C5 and C6 had higher ( $\mathrm{p}<0.05)$ ash content compared $\mathrm{C} 1$ and $\mathrm{C} 2$ (short time frying cycle). This showed that ash content was increased as frying cycle increases. The higher ash content of fried fish might be due to the lower in moisture content and uptake of oil during frying. This study agree with Steiner-Asiedu et al. (1991) who reported that higher ash content in fried sardine fish.

Crude fat content of fried fish varied from 29.06 to 34.66\%. Fried fish from different cycles (C1, C2, C3, C4, $\mathrm{C} 5$ and $\mathrm{C} 6)$ had higher $(\mathrm{p}<0.05)$ crude fat compared to un-fried fish $(\mathrm{CR})$. However, fried fishes from $\mathrm{C} 4, \mathrm{C} 5$ and $\mathrm{C} 6$ had similar $(\mathrm{p} \geq 0.05)$ crude fat compared to reference (CL-commercial fried fish). Fried fishes from $\mathrm{C} 1, \mathrm{C} 2$ and $\mathrm{C} 3$ had lower $(\mathrm{p}<0.05)$ crude fat compared to $(\mathrm{CL}-\mathrm{commercial}$ fried fish). With regard to effects of frying cycles, $\mathrm{C} 3, \mathrm{C} 4, \mathrm{C} 5$ and $\mathrm{C} 6$ had higher $(\mathrm{p}<0.05)$ crude fat compared $\mathrm{C} 1$ and $\mathrm{C} 2$ (short frying cycles). This showed increasing the frying cycle increased the crude fat of fried fish. The higher in crude fat might be due to frying oil is stayed longer and drawn in to fish after moisture is lost by evaporation during frying (Ghidurus, 2010). This study is consistent with (Aberoumand, 2014) who reported the lowering of moisture results fat to be drawn in to frying fish.

Crude protein of fried fish varied from 49.15 to $44.3 \%$. Fried fish from different cycles $(\mathrm{C} 1, \mathrm{C} 2, \mathrm{C} 3, \mathrm{C} 4, \mathrm{C} 5$ and C6) had lower $(\mathrm{p}<0.05)$ crude protein compared to un-fried fish $(\mathrm{CR})$. However, fried fishes from $\mathrm{C} 4, \mathrm{C} 5$ and $\mathrm{C} 6$ had similar $(\mathrm{p} \geq 0.05)$ crude protein compared to reference (CL-commercial fried fish). Fried fishes from $\mathrm{C} 1$, $\mathrm{C} 2$ and $\mathrm{C} 3$ had higher $(\mathrm{p}<0.05)$ crude protein compared to $(\mathrm{CL}$-commercial fried fish). From frying cycle's aspect, $\mathrm{C} 4, \mathrm{C} 5$ and $\mathrm{C} 6$ had lower $(\mathrm{p}<0.05)$ crude protein compared to $\mathrm{C} 1, \mathrm{C} 2$ and $\mathrm{C} 3$ (short frying cycles). This showed increasing the frying cycle decreased the crude protein of fried fish. The lower in crude protein for fish fried in higher cycles might be due to destruction of some amino acid and formation of aldehydes, epoxides, hydroxyketones, and dicarboxylic compounds when lipid is oxidized during deep frying and reaction with the amines of amino acids of proteins in fried foods (Choe and Min, 2007). The finding of this study is consistent with the study of (Henry, 1998; Oluwaniyi et al., 2010) who reported that protein content of marine fish was decreased during deep frying with palm oil. Garcia-Arias et al., (2003a) also reported that the water losses during frying 
resulted low protein content in fried fish as compared to raw fish.

Total carbohydrate of fried fish varied considerable from 7.07 to $6.50 \%$. The carbohydrate level of all fried fish were comparable $(\mathrm{p}>0.05)$. Significance difference was not observed on total carbohydrate of raw fish, fish fried from cycle $\mathrm{C} 1$ to cycle C6 and CL- commercial fried fish, this might be due carbohydrate is obtained by difference method and it is minor component of fish.

\section{Selected mineral content of raw and deep fried fish with recycled palm oil}

Calcium content of fried fish varied considerably from 1.93 to $1.25 \%$. Fried fishes from $(\mathrm{C} 3, \mathrm{C} 4, \mathrm{C} 5$ and $\mathrm{C} 6)$ had lower $(\mathrm{p}<0.05)$ calcium content compared to un-fried fish $(\mathrm{CR})$. However, fried fishes from $(\mathrm{C} 1$ and $\mathrm{C} 2) \mathrm{had}$ similar ( $p \geq 0.05$ ) calcium content compared to un-fried fish (CR). Furthermore, fried fishes from C4, C5 and C6 had similar ( $\mathrm{p} \geq 0.05)$ calcium content compared to reference (CL-commercial fried fish). Fried fishes from C1, C2 and $\mathrm{C} 3$ had higher $(\mathrm{p}<0.05)$ calcium content compared to reference (CL-commercial fried fish). Concerning to frying cycles effect, C3, C4, C5 and C6 had lower $(\mathrm{p}<0.05)$ calcium content compared to C1 and C2 (lower frying cycles). This showed that increasing the frying cycle decreased calcium content of fried fish. The change in calcium content might be due to alteration of fatty acid composition. (Lukaski et al., 1982) reported that fatty acid alteration has slight effect on calcium and iron content rainbow trout fish. The finding of this study is consistent with (Pokorny, 1999; Gokoglu et al., 2004).

Phosphorus content of fried fishes varied from 2.00 to $1.15 \%$. Fried fish from (C4, C5 and C6) had lower $(\mathrm{p}<0.05)$ phosphorus content compared to un-fried fish $(\mathrm{CR})$. However, fried fishes from $(\mathrm{C} 1, \mathrm{C} 2$ and $\mathrm{C} 3) \mathrm{had}$ similar ( $\mathrm{p} \geq 0.05$ ) phosphorus content compared to un-fried fish (CR). Furthermore, fried fishes from $\mathrm{C} 4, \mathrm{C} 5$ and C6 had similar ( $\mathrm{p} \geq 0.05)$ phosphorus content compared to reference (CL-commercial fried fish). Fried fishes from $\mathrm{C} 1, \mathrm{C} 2$ and $\mathrm{C} 3$ had higher $(\mathrm{p}<0.05)$ phosphorus content compared to reference (CL-commercial fried fish). Concerning to effect of frying cycles, C5 and C6 had lower $(\mathrm{p}<0.05)$ phosphorus content compared C1, C2 and $\mathrm{C} 3$ and fried fish from $\mathrm{C} 4$ is intermediate. This showed that increasing the frying cycle decreased the phosphorus content of fried fish. The change in phosphorus content might be due to metal content is expressed in dry weight base. This study is in line with (Steiner-Asiedu et al., 1991; Ghidurus et al., 2010; Asghari et al., 2013).

Iron content of fried fishes varied considerably from 19.65 to $18.01 \mathrm{mg} / \mathrm{Kg}$. Fried fishes from $(\mathrm{C} 4, \mathrm{C} 5 \mathrm{and}$ C6) had lower $(\mathrm{p}<0.05)$ iron content compared to un-fried fish $(\mathrm{CR})$. However, fried fishes from $(\mathrm{C} 1, \mathrm{C} 2$ and $\mathrm{C} 3)$ had similar ( $\mathrm{p} \geq 0.05)$ iron content compared to un-fried fish (CR). Furthermore, fried fishes from C4, C5 and C6 had similar ( $\mathrm{p} \geq 0.05)$ iron content compared to reference (CL-commercial fried fish). Fried fish from C1, C2 and $\mathrm{C} 3$ had higher $(\mathrm{p}<0.05)$ iron content compared to reference $(\mathrm{CL}-\mathrm{commercial}$ fried fish). Regarding frying cycles effect, C4, C5 and C6 had lower $(\mathrm{p}<0.05)$ iron content compared to fried from $\mathrm{C} 1$ and $\mathrm{C} 2$ (lower cycles). Fried fish from $\mathrm{C} 3$ is an intermediate between $\mathrm{C} 1, \mathrm{C} 2$ and $\mathrm{C} 4, \mathrm{C} 5$. This showed that increasing the frying cycle decreased iron content of fried fish. The lower iron content might be due to alteration of fatty acid composition (Ersoy and Özeren, 2009). The finding of this study is consistent with (Ackurt, 1991; Gokoglu et al., 2004).

Zinc content of fried fish varied from 38.40 to $31.14 \mathrm{mg} / \mathrm{Kg}$. Fried fish from different cycles $(\mathrm{C} 1, \mathrm{C} 2, \mathrm{C} 3, \mathrm{C} 4$, $\mathrm{C} 5$ and C6) had similar ( $\mathrm{p} \geq 0.05$ ) zinc content compared to un-fried fish (CR) and reference (CL-commercial fried fish). However, un-fried fish and commercial fried fish are significantly different $(p<0.05)$. Regarding to effects of frying cycles, C1, C2, C3, C4, C5 and C6 had similar $(\mathrm{p}<0.05)$ zinc content. This showed that increasing the frying cycle has no significant effect on zinc content. This study is consistent with (Gall, 1983; Pokorny, 1999) who reported that frying has little or no effect on mineral content of fried chicken. Generally; loss of mineral might be due to the leaching of mineral into frying medium or the increase in cell separation fried fish during deep frying. Ghidurus et al., (2010) reported that minerals would be soluble in trace amount in frying oil during deep frying.

\section{Consumer oriented sensory evaluation}

The color of fried fish varied from 3.32 to 2.80. Fried fishes from different cycle (C3, C4, C5 and C6) had similar $(p \geq 0.05)$ color acceptability with each other and they had lower $(p<0.05)$ color acceptability compared to fried fish from frying cycle $(\mathrm{C} 1)$. Fried fish from frying cycle $(\mathrm{C} 2)$ had similar $(\mathrm{p} \geq 0.05)$ color acceptability compared to fried fishes from frying cycles $(\mathrm{C} 1$ and $\mathrm{C} 3)$. However, fried fish from frying cycle $(\mathrm{C} 2)$ had higher $(\mathrm{p}<0.05)$ color acceptability compared to fried fishes from frying cycle (C4, C5 and C6). This showed that color acceptability was decreased as the frying cycle increase. The lower color acceptability might be due to darkness of oil as pigment (nonvolatile decomposition products [NVDPs] is developed and thermal decomposition of fatty acids, which later diffuse in the oil and affect color of palm oil and frying fish. Furthermore, the lower color acceptability might also be due to formation of trace carotenoid during deep frying of oil and accelerate in reduction of lightness value (Lvalue) in oil (Nor et al., 2008). The finding of this study was in agreement with.

The flavor of fried fish varied from 3.36 to 2.89. Fried fishes from different cycle (C3, C4, C5 and C6) had similar $(p \geq 0.05)$ flavor acceptability with each other and they had lower $(p<0.05)$ flavor acceptability compared to fried fish from frying cycle $(\mathrm{C} 1)$. Fried fish from frying cycle $(\mathrm{C} 2)$ had similar $(\mathrm{p} \geq 0.05)$ flavor acceptability compared to fried fishes from frying cycles $(\mathrm{C} 1, \mathrm{C} 3$. C4 and C5), but fried fish from frying cycle $(\mathrm{C} 2)$ had higher $(\mathrm{p}<0.05)$ flavor acceptability compared to fried fish from frying cycle $(\mathrm{C} 6)$. This showed that flavor acceptability was decreased as frying cycle increase. The lower flavor acceptability might be due to formation of secondary 
oxidation product (free fatty acid) and this compound can develop off flavor in palm oil and this off flavor might influence frying fish. The study of this finding is in agreement with (Debnath et al., 2012).

The odor of fried fish varied from 3.30 to 2.86. Fried fishes from different cycles (C4, C5 and C6) had similar $(\mathrm{p} \geq 0.05)$ odor acceptability with each other and they had lower $(\mathrm{p}<0.05)$ odor acceptability compared to fried fishes from frying cycle ( $\mathrm{C} 1$ and $\mathrm{C} 2)$. Fried fish from frying cycle $(\mathrm{C} 3)$ is an intermediate between $(\mathrm{C} 1, \mathrm{C} 2$ and $\mathrm{C} 4, \mathrm{C} 5)$. This showed that odor acceptability decreased as frying cycle increase. The lower odor acceptability might be due to formation of peroxide and free radical compound which later leads to formation of secondary oxidation compound (free fatty acid) and this compound could develop off odor in palm oil and might influence frying fish. The finding of this study is in line with (Ketaona et al., 2013).

Fried fish from frying cycles $(\mathrm{C} 3, \mathrm{C} 4$ and $\mathrm{C} 5)$ had lower $(\mathrm{p}<0.05)$ appearance acceptability compared to fried fishes from frying cycle (C1 and C2). However, Fried fishes from frying cycle (C3, C4 and C5) had higher ( $p<0.05)$ appearance acceptability compared to fried fish from frying cycle (C6). This showed that appearance acceptability was decreased as frying cycle increase. The lower appearance acceptability might be associated with color and darkness of frying oil due to reusing continuously which might also influence the feature of fried products.

Overall acceptability of fried fish varied from 3.47 to 3.02. Fried fishes from cycle one (C1) had highly $(\mathrm{p}<0.05)$ accepted compared to $\mathrm{C} 4, \mathrm{C} 5$ and C6. However, it had similar $(\mathrm{p}>0.05)$ acceptability with frying cycle two (C2) and frying cycle three (C3). This showed that overall acceptability was decreased as frying cycle increase. The lower acceptability might be associated with changes occur in oil due to repeated uses and this has influence on color, flavor, odor, appearance and generally overall acceptability of fried fish as frying cycle increase. According to Debnath et al. (2012) the oil change's its color and become dark due to repeatedly frying and this has influence on acceptability of fried product.

\section{Conclusion}

Repeatedly using of frying oil is common practice to minimize the cost of frying oil. The study showed, reusing of frying oil can keeps down crude protein and moisture content of fried fish. However, reusing of frying oil enhance ash and crude fat content. Fried fish from short frying cycle is relatively high crude protein and moisture content but low ash and crude fat content as compared to fried fish from high frying cycle. Similarly, repeatedly used frying oil has impact on minerals ( $\mathrm{Ca}, \mathrm{P}, \mathrm{Fe}$ and $\mathrm{Zn})$ and sensory acceptability of deep fried fish. Therefore, reusing of frying oil for fish frying is unsafe from health aspect.

\section{Reference}

Aberoumand, A., 2014. Nutrient composition analysis of gish fish fillets affected by different cooking methods. International Food Research Journal, 21(5), p.1989.

Ackurt, F., 1991. Nutrient retention during preparation and cooking of meat and fish by traditional methods. Gida Sanayii, 20, pp.58-66.

Alemu, Y., Snoeks, J., Teklegiorgis, Y4., Nyssen, $J^{4}$. And Brendoncj, L6 ., 2017. Assessing Sustainable Fishing Yields Using Length-based Analytical Models: A Case Study with Nile Tilapia in Lake Hawassa (Ethiopia). Journal of Fisheries \& Livestock Production, Vol 5(4): 255.

Al-Saghir, S., Thurner, K., Wagner, K.H., Frisch, G., Luf, W., Razzazi-Fazeli, E. and Elmadfa, I., 2004. Effects of different cooking procedures on lipid quality and cholesterol oxidation of farmed salmon fish (Salmo salar). Journal of Agricultural and Food Chemistry, 52(16), pp.5290-5296.

AOAC, 1998. Official Methods of Analysis of the Association of Official Analytical Chemists, In: Horwitz, W, Methods, 925.05, 18th ed. Washington, DC.

AOAC, 2000. Official Methods of Analysis of the Association of Official Analytical Chemists, In: Horwitz, W, Methods, 925.05, 18th ed. Washington, DC.s

Asghari, L., Zeynali, F., \& Sahari, M. A., 2013. Effects of boiling, deep-frying, and microwave treatment on the proximate composition of rainbow trout fillets: Changes in fatty acids, total protein and minerals. Journal of Applied Ichthyology, 29, 847-853. issue-4.

Benedito, J., García-Pérez, J.V., Dobarganes, M.C., Mulet, A., 2007. Rapid evaluation of frying oil degradation using ultrasonic technology. Food Research International 40 (3), 406-414.

Choe, E. and Min, D.B., 2007. Chemistry of deep fat frying oils. Journal of Food Science, 72(5), pp.R77-R86.

Chukwu, O. and Shaba, I.M., 2009. Effects of drying methods on proximate compositions of catfish (Clarias gariepinus). World Journal of Agricultural Sciences, 5(1), pp.114-116.

Debnath, S., Rastogi, N.K., Krishna, A.G. and Lokesh, B.R., 2012. Effect of frying cycles on physical, chemical and heat transfer quality of rice bran oil during deep-fat frying of poori: An Indian traditional fried food. Food and bioproducts processing, 90(2), pp.249-256.

Echarte, M., Zulet., M.A, Astiasarán, I., 2001. Oxidation process affecting fatty acids and cholesterol in fried and roasted salmon. Journal of Food Chemistry, 49(11):5662-5667.

Ersoy, B. and Özeren, A., 2009. The effect of cooking methods on mineral and vitamin contents of African 
catfish. Food Chemistry, 115(2), pp.419-422.

Gall, K.L., Otwell, W.S., Koburgier, J.A. and Appledorf, H., 1983. Effects of four cooking methods on the proximate, mineral and fatty acid composition of fish fillets. Journal of Food Science, 48(4), pp.1068-1074.

Garcia-Arias, M.T., Alvarez-Pontes, E., García-Fernández, M.C. and Sánchez-Muniz, F.J., 2003. Freezing/defrosting/frying of sardine fillets. Influence of slow and quick defrosting on protein quality. Journal of Food Science and Agriculture, 83(6), pp.602-608.

Ghidurus, M.I.H.A.E.L.A., Turtoi, M., Boskou, G., Niculita, P.E.T.R.U. and Stan, V., 2010. Nutritional and health aspects related to frying (I). Romanian Biotechnological Letters, 15(6), pp.5675-5682.

Gokoglu, N., Yerlikaya, P. and Cengiz, E., 2004. Effects of cooking methods on the proximate composition and mineral contents of rainbow trout (Oncorhynchus mykiss). Journal Food Chemistry, 84(1), pp.19-22.

Henry, C.K., 1998. Impact of fried foods on macronutrient intake, with special reference to fat and protein. Grasas y aceites, 49(3-4), pp.336-339.

Kebede, A., Meko, T., Hussein, A. and Tamiru, Y., 2017. Review on Opportunities and Constraints of Fishery in Ethiopia. Intenational Journal of Poultry and Fish Science, 1(1), pp.1-8.

Ketaona, A.D.A., Clerge, T. and Bertrand, N.G., 2013. Quality of Ricinodendron heudelotii (Bail.) pierre ex pax seeds oil as affected by heating. International Journal of Engineer Research Science and Technology, 2, pp.94-100.

Lukaski, H.C., Klevay L.M., Bolonchuk, W.W., Mahaiko, J.R., Milne, D.B., Johnson, LK., Sandstead, H.H., 1982. «Influence of fatty acid alteration on iron, zinc and copper» Fed Proc, 41, 275 (abs.).

Mellema, M., 2003. Mechanism and reduction of fat uptake in deep-fat fried foods. Trends in Food Science \& Technology, 14(9), pp.364-373.

Moradi, Y., Bakar, J., Motalebi, A. A., Syed Muhamad, S. H., \& Che Man, Y., 2011. A review on fish lipid composition and changes during cooking methods. Journal of Aquatic Food Product Technology, 20(4), 379390.

Njinkoue, J.M., Gouado, I., Tchoumbougnang, F., Ngueguim, J.Y., Ndinteh, D.T., Fomogne-Fodjo, C.Y. and Schweigert, F.J., 2016. Proximate composition, mineral content and fatty acid profile of two marine fishes from Cameroonian coast: Journal of Nutrition and Food Science, 4, pp.27-31.

Nor, F.M., Mohamed, S., Idris, N.A. and Ismail, R., 2008. Antioxidative properties of Pandanus amaryllifolius leaf extracts in accelerated oxidation and deep frying studies. Journal of Food chemistry, 110(2), pp.319-327.

Oluwaniyi OO, Dosumu OO, Awolola GV., 2010. Effect of local processing methods (boiling, frying and roasting) on the amino acid composition of four marine fishes commonly consumed in Nigeria. Journal of Food Chemistry, 123: 1000-1006.

Pokorny, J., 1999. Changes of nutrients at frying temperatures. Frying of food Oxidation, nutrient and non-nutrient antioxidants, biologically active compounds and high temperatures. Technomic, Lancaster, PA, pp.69-103.

Rossi, M., Alamprese, C., Rattia, S., Riva1, M., 2009. Suitability of contact angle measurement as an index of overall oil degradation and oil uptake during frying. Journal of Food Chemistry 112 (2), 448-452.

Steiner-Asiedu, M., Julshamn, K. and Lie, O., 1991. Effect of local processing methods (cooking, frying and smoking) on three fish species from Ghana. I. Proximate composition, fatty acids, minerals, trace elements and vitamins. Journal of Food Chemistry. 40 309-321.

Vijverberg, J., Dejen, E., Getahun, A. and Nagelkerke, L.A., 2012. The composition of fish communities of nine Ethiopian lakes along a north-south gradient: threats and possible solutions. Animal Biology, 62(3), pp.315335.

Weber, J., Bochi, V.C., Ribeiro, C.P., Victório, A.D.M. and Emanuelli, T., 2008. Effect of different cooking methods on the oxidation, proximate and fatty acid composition of silver catfish (Rhamdia quelen) fillets. Journal of Food Chemistry, 106(1), pp.140-146. 
Table 1: Socio-demographic, processing and safety issue of Fish at Hawassa Lake side

\begin{tabular}{|c|c|c|c|c|c|}
\hline \multicolumn{2}{|l|}{ Socio demography } & \multicolumn{2}{|l|}{$\begin{array}{l}\text { Fish preparation and } \\
\text { processing }\end{array}$} & \multicolumn{2}{|l|}{ Safety issue } \\
\hline Total Size & $18(100 \%$ & Total Size & $18(100 \%$ & & $\mathrm{N}=18$ \\
\hline $\begin{array}{l}\text { Educational level of } \\
\text { fryer }\end{array}$ & \multirow{4}{*}{$\begin{array}{l}1(5.6) \\
13(72.2) \\
3(16.7)\end{array}$} & $\begin{array}{l}\text { Raw fish purchasing per } \\
\text { day }\end{array}$ & \multirow{4}{*}{$\begin{array}{l}6(33.3) \\
5(27.8) \\
7(38.9)\end{array}$} & \multirow{3}{*}{$\begin{array}{l}\text { Fish storing room } \\
\text { (ice room) } \\
\text { Yes } \\
\text { No }\end{array}$} & \\
\hline Illiterate & & 40 & & & $15(83.3)$ \\
\hline Primary school & & 60 & & & $3(16.7)$ \\
\hline Secondary school & & Above 60 & & \multirow{3}{*}{$\begin{array}{l}\text { raw fish Storage } \\
\text { after purchasing } \\
\text { Ice room }\end{array}$} & \\
\hline College and above & $1(5.6)$ & $\begin{array}{l}\text { storage time before } \\
\text { frying after purchasing }\end{array}$ & \multirow{3}{*}{$\begin{array}{l}3(16.7) \\
3(16.7)\end{array}$} & & $15(83.3)$ \\
\hline \multirow{2}{*}{$\begin{array}{l}\text { Sex } \\
\text { Male }\end{array}$} & \multirow[b]{2}{*}{$16(88.88)$} & Immediately & & & $3(16.7)$ \\
\hline & & $5 \mathrm{~min}$ & & $\begin{array}{l}\text { Well informed } \\
\text { about food safety }\end{array}$ & \\
\hline Female & $2(11.11)$ & $10 \mathrm{~min}$ & $9(50.0)$ & Yes & $2(11.1)$ \\
\hline \multirow{2}{*}{$\begin{array}{l}\text { Working experience } \\
\text { in fish market } \\
6 \text { month }\end{array}$} & \multirow[b]{2}{*}{$3(16.7)$} & $15 \mathrm{~min}$ & $3(16.7)$ & No & $16(88.9)$ \\
\hline & & $\begin{array}{l}\text { Fish } \\
\text { Preparation(processing) }\end{array}$ & & $\begin{array}{l}\text { Duration of oil used } \\
\text { for frying }\end{array}$ & \\
\hline \multirow{14}{*}{$\begin{array}{l}1 \text { year } \\
2 \text { year } \\
\text { Above } 2 \text { year }\end{array}$} & \multirow{14}{*}{$\begin{array}{l}8(44.4) \\
5(27.8) \\
2(11.1)\end{array}$} & Fry & $18(100.0)$ & 1 day & $11(61.1)$ \\
\hline & & Fillet & $0(0)$ & 2 day & $7(38.9)$ \\
\hline & & Type of fish usually fry & & $\begin{array}{lr}\text { Reusing } & \text { of } \begin{array}{r}\text { oil } \\
\text { during }\end{array} \\
\text { (cycle) } & \text { frying }\end{array}$ & \\
\hline & & Nile tilapia (Koroso) & $18(100.0)$ & 5 cycle & $6(33.3)$ \\
\hline & & cate fish (Ambza) & $0(0)$ & 6 cycle & $12(66.7)$ \\
\hline & & $\begin{array}{l}\text { Type of fish usually } \\
\text { consumed }\end{array}$ & & More than 6 cycle & $0(0)$ \\
\hline & & Nile tilapia (koroso) & $18(100.0)$ & \multirow{3}{*}{$\begin{array}{l}\text { Action for Last used } \\
\text { oil } \\
\text { Purge } \\
\text { Fire } \\
\text { Sell }\end{array}$} & \\
\hline & & Cate fish (Ambaza) & $0(0)$ & & $15(83.3)$ \\
\hline & & $\begin{array}{l}\text { Time taken during } \\
\text { frying } \\
5 \mathrm{~min}\end{array}$ & $2(11.1)$ & & $\begin{array}{l}3(16.7) \\
0(0)\end{array}$ \\
\hline & & $10 \mathrm{~min}$ & $14(77.8)$ & \multirow{3}{*}{\multicolumn{2}{|c|}{$\begin{array}{ll}\begin{array}{l}\text { Storing fried } \\
\text { before serving }\end{array} & \\
5 \mathrm{~min} & 5(27.8) \\
15 \mathrm{~min} & 1(5.6) \\
\geq 30 \mathrm{~min} & 12(66.7) \\
\end{array}$}} \\
\hline & & $15 \mathrm{~min}$ & $2(11.1)$ & & \\
\hline & & $\begin{array}{l}\text { Amount of oil used } \\
\text { during frying } \\
5 \text { litter }\end{array}$ & $14(77.8)$ & & \\
\hline & & $\begin{array}{l}10 \text { litter } \\
\text { Above } 10 \text { litter }\end{array}$ & $\begin{array}{l}4(22.2) \\
0(0)\end{array}$ & \multirow{2}{*}{$\begin{array}{l}\text { A place for storing } \\
\text { fried fish } \\
\text { Open air (outdoor) } \\
\text { In door }\end{array}$} & \multirow{2}{*}{$\begin{array}{l}18(100.0) \\
0(0)\end{array}$} \\
\hline & & $\begin{array}{l}\text { Mostly used type of oil } \\
\text { for frying } \\
\text { Palm } \\
\text { Frying oil }\end{array}$ & $\begin{array}{l}18(100 \%) \\
0(0)\end{array}$ & & \\
\hline
\end{tabular}


Proximate composition of raw and deep fried fish with recycled palm oil

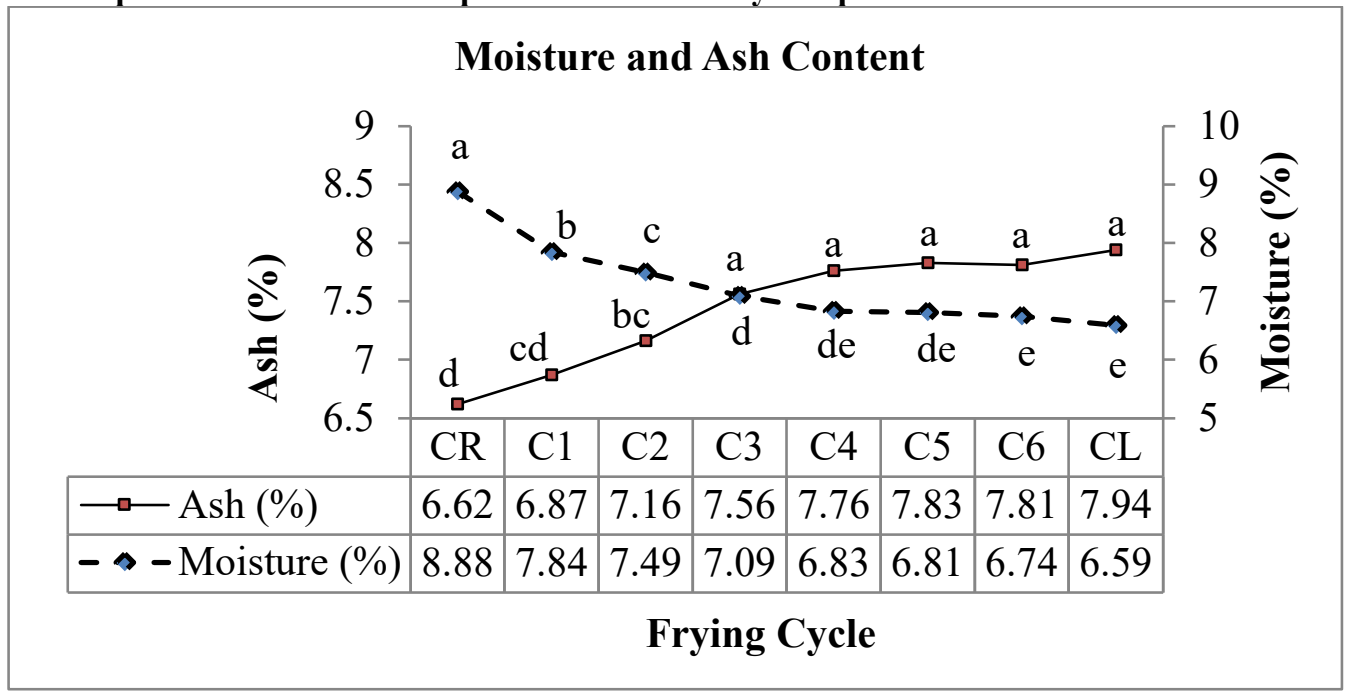

Figure 1: Moisture and Ash content of raw and deep fried tilapia fish

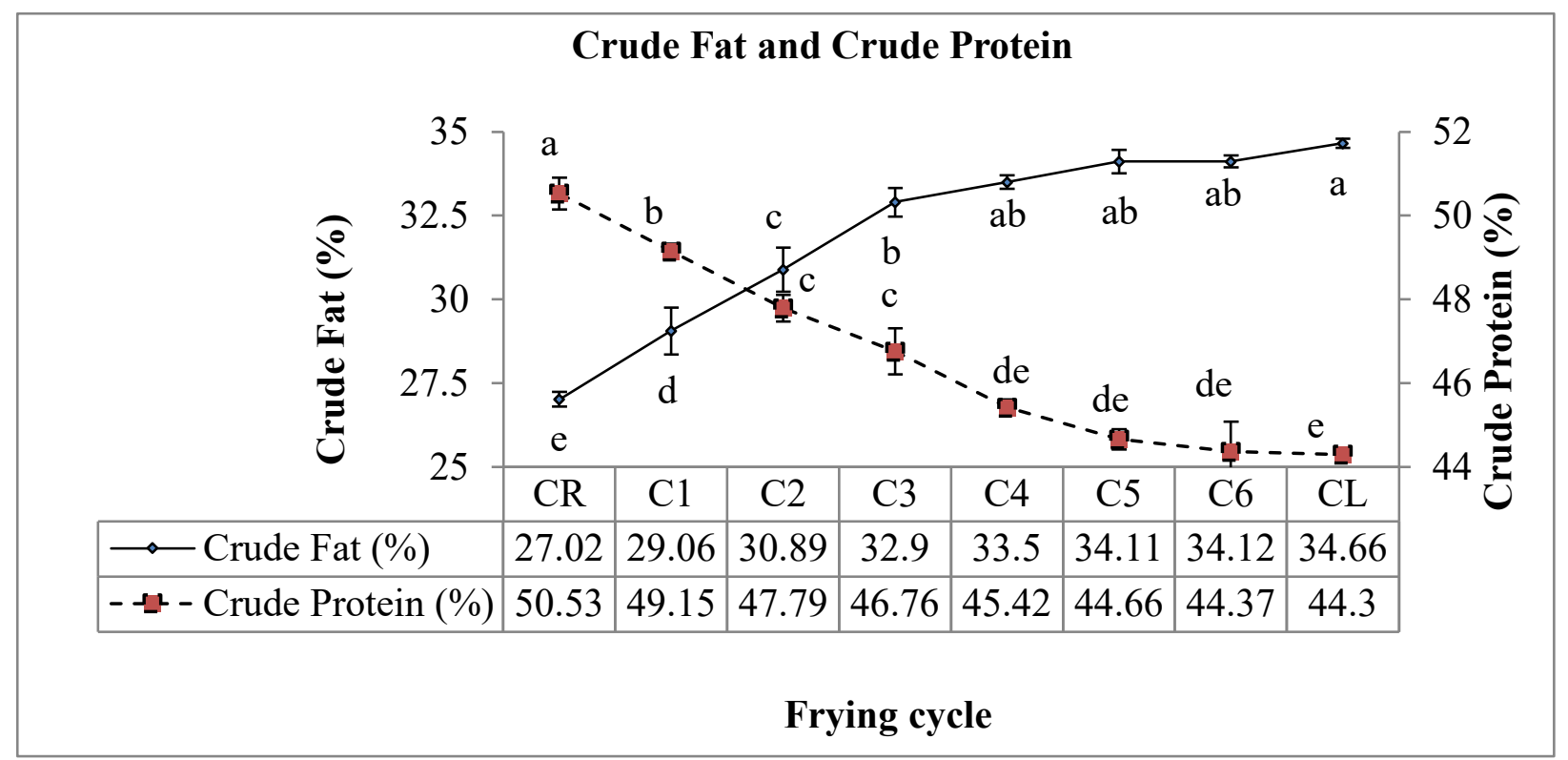

Figure 2: Crude fat and Crude protein content of raw and deep fried tilapia fish 
Minerals content of raw and deep fried fish with recycled palm oil

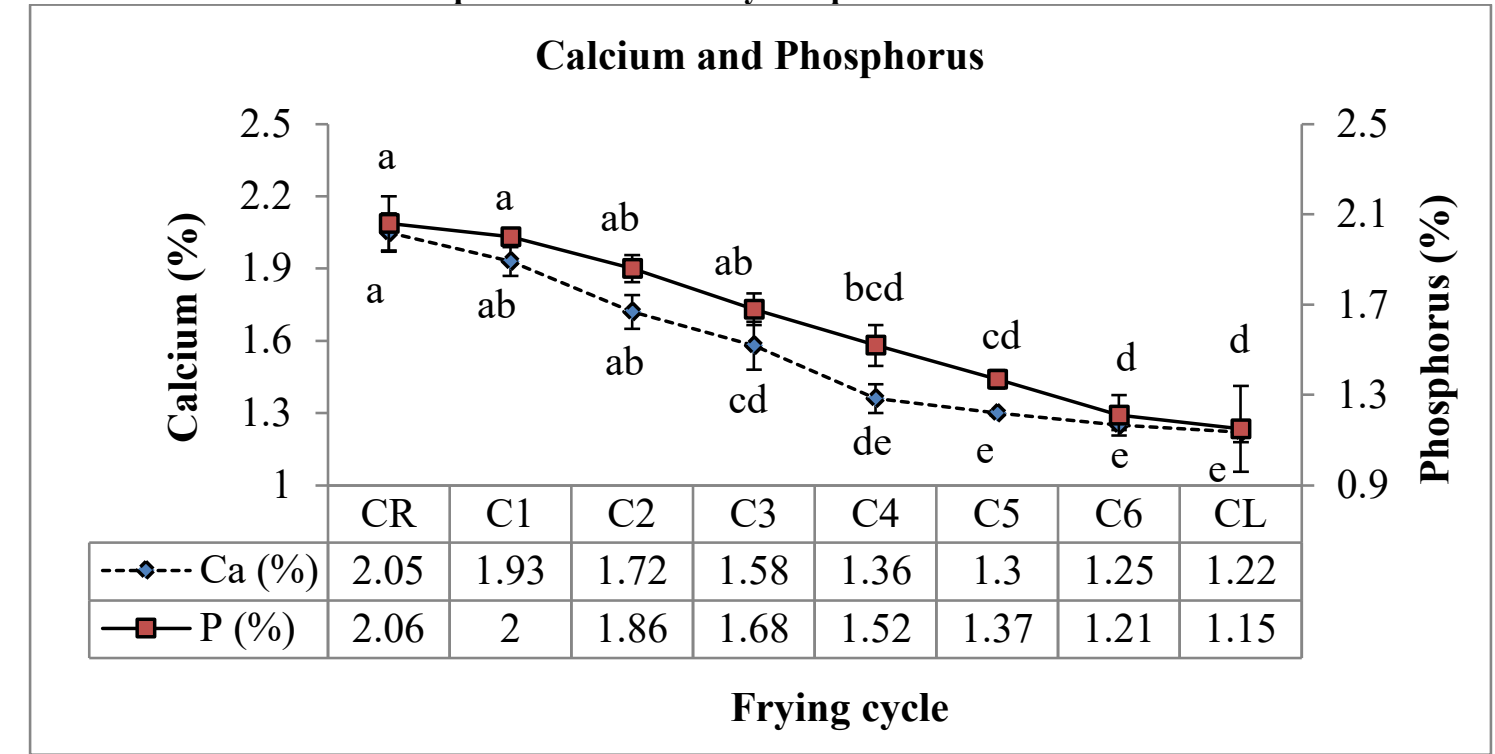

Figure 3: Calcium and phosphorus content of raw and deep fried Nile tilapia fish

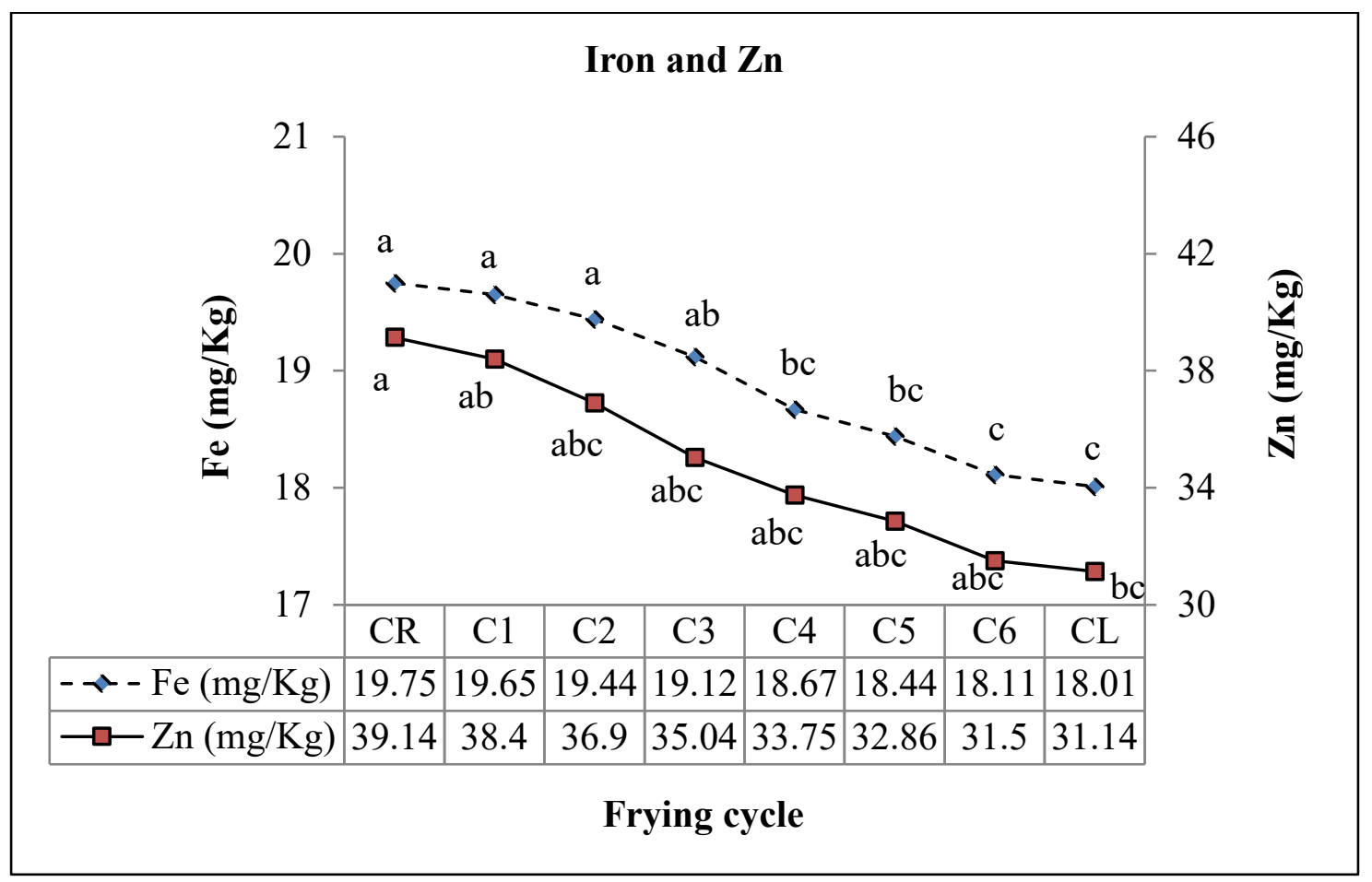

Figure 4: Iron and Zinc content of raw and deep fried Nile tilapia fish 


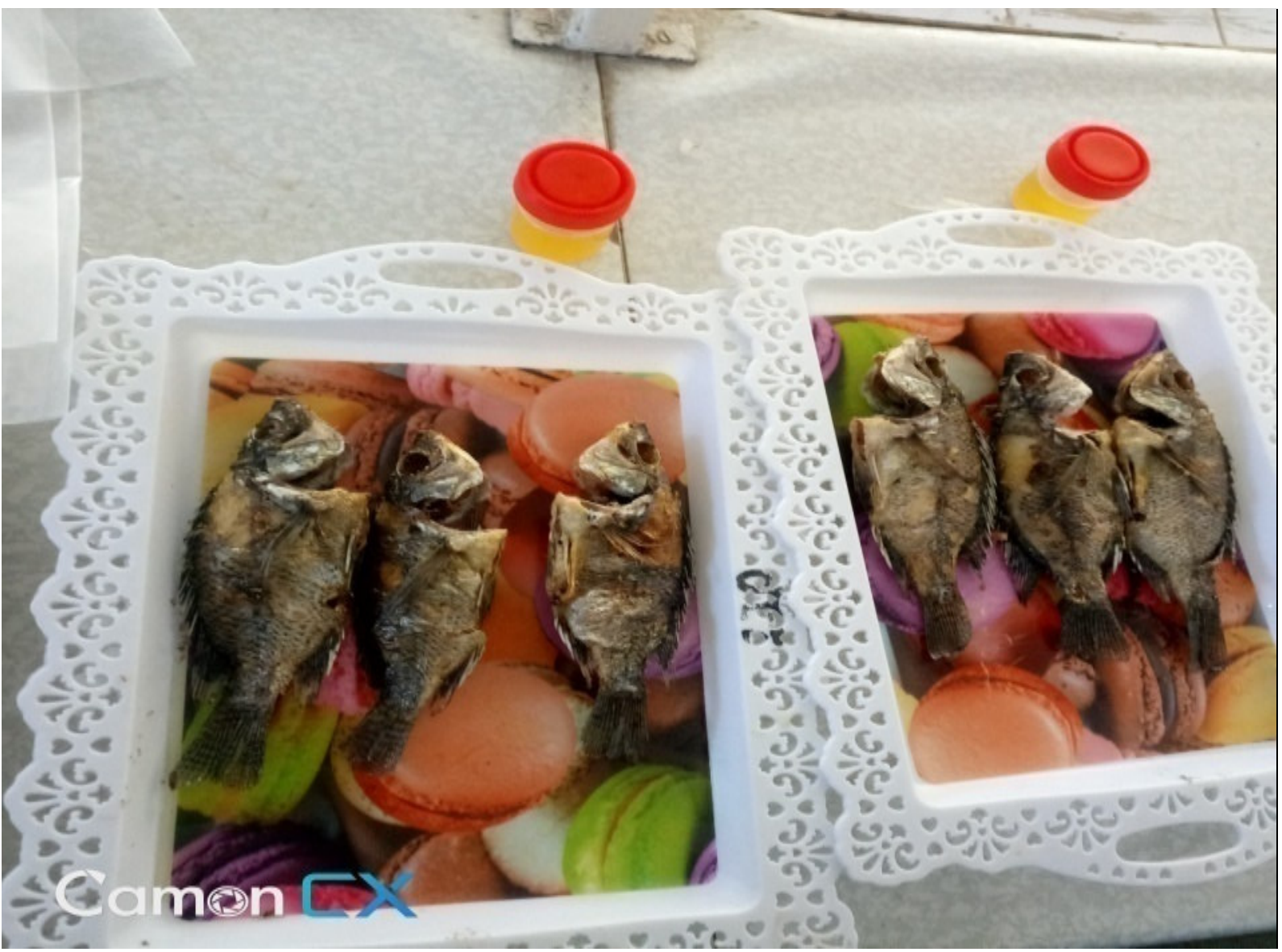

Figure 5: Deep fried fish with repeatedly used palm oil and Palm oil used for frying

Table 4.5: Sensory acceptability of fried fish

\begin{tabular}{llllll}
\hline Frying cycle & Color & Flavor & Odor & Appearance & Over all \\
\hline C1 & $3.32 \pm 0.47^{\mathrm{a}}$ & $3.36 \pm 0.48^{\mathrm{a}}$ & $3.30 \pm 0.46^{\mathrm{a}}$ & $3.36 \pm 0.48^{\mathrm{a}}$ & $3.47 \pm 0.50^{\mathrm{a}}$ \\
C2 & $3.21 \pm 0.41^{\mathrm{ab}}$ & $3.15 \pm 0.41^{\mathrm{ab}}$ & $3.26 \pm 0.44^{\mathrm{a}}$ & $3.23 \pm 0.43^{\mathrm{ab}}$ & $3.39 \pm 0.49^{\mathrm{ab}}$ \\
C3 & $3.02 \pm 0.14^{\mathrm{bc}}$ & $3.04 \pm 0.29^{\mathrm{bc}}$ & $3.13 \pm 0.34^{\mathrm{ab}}$ & $3.08 \pm 0.28^{\mathrm{c}}$ & $3.32 \pm 0.47^{\mathrm{ab}}$ \\
C4 & $2.93 \pm 0.24^{\mathrm{c}}$ & $3.00 \pm 0.21^{\mathrm{bc}}$ & $3.00 \pm 0.21^{\mathrm{bc}}$ & $2.97 \pm 0.14^{\mathrm{cd}}$ & $3.13 \pm 0.40^{\mathrm{bc}}$ \\
C5 & $2.89 \pm 0.31^{\mathrm{c}}$ & $2.95 \pm 0.29^{\mathrm{bc}}$ & $2.97 \pm 0.25^{\mathrm{bc}}$ & $2.86 \pm 0.34^{\mathrm{cd}}$ & $3.10 \pm 0.43^{\mathrm{bc}}$ \\
C6 & $2.80 \pm 0.40^{\mathrm{c}}$ & $2.89 \pm 0.37^{\mathrm{cd}}$ & $2.86 \pm 0.40^{\mathrm{cd}}$ & $2.78 \pm 0.41^{\mathrm{e}}$ & $3.02 \pm 0.39^{\mathrm{cd}}$ \\
\hline
\end{tabular}

Where C1 is fried cycle 1, C2 is fried cycle 2, C3 is fried cycle 3, C4 is fried cycle 4, C5 is fried cycle 5 and C6 is fried cycle 6 . Values are (mean \pm standard deviation). Mean followed by different superscript letter within the column indicates significantly different at $(\mathrm{P}<0.05)$. 